\title{
Lack of effect of exogenous insulin-like growth factor-I (IGF-I) on chick embryo growth rate
}

\author{
GSG Spencer 1*, GJ Garssen 2, AR Gerrits 3, \\ EM Spencer 4 , SC Kestin 5 \\ 1 Ruakura Agricultural Centre, MAF, Hamilton, New Zealand; \\ 2 Research Institute for Animal Production "Schoonoord", PO Box 501, 3700 AM Zeist; \\ ${ }^{3}$ Centre for Poultry Research and Extension, "Het Spelderholt", Beekbergen, The Netherlands; \\ ${ }^{4}$ Childrens' Hospital, San Francisco, CA, USA; \\ 5 Institute of Food Research, Langford, Bristol, UK
}

(Received 28 February 1990; accepted 23 May 1990)

\begin{abstract}
Summary - Direct evidence that IGF-I has any significant effect on embryo growth is lacking. We therefore studied the effect of administration of IGF-I on the chick embryo in ovo. Five hundred ng pure IGF-I (purified from human plasma) were given to chick embryos on 2 occasions ( 7 and $14 \mathrm{~d}$ ) by injection directly into the allantoic sac. Treated and control (saline injected) chicks hatched on the same day and were killed. IGF-I appeared to reach the tissues as the [35S]-sulphate uptake of treated sternal cartilage was significantly greater than that of control $(P<0.02)$. However, there were no significant effects of treatment on total body weight, bone length measurements, organ (lung, liver, heart) weights, muscle DNA, RNA or protein levels. From these results we conclude that administration of exogenous IGF-I to the chick embryo at 7 and $14 \mathrm{~d}$ does not stimulate further growth of the chick embryo.
\end{abstract}

IGF-I / chick / embryo / growth

Résumé - Absence d'effet de l'IGF-I exogène sur la croissance de l'embryon de poulet. II n'existe aucune preuve expérimentale que l'IGF-I exerce un effet significatif sur la croissance pondérale de l'embryon de poulet. Nous avons donc étudié l'effet de l'administration de 500 ng d'IGF-l pur injecté in ovo à j7 et j14 dans le sac allantö̈dien. Tous les ceufs ont éclos le même jour et les poussins traités et témoins (ayant reçu le solvant) ont été sacrifiés. Nous avons observé une incorporation de sulfate marqué ${ }^{35}$ S] significativement plus importante dans le cartilage du sternum des animaux traités que dans celui des témoins. Ceci indique que l'IGF-I injecté a atteint les tissus embryonnaires. Toutefois, nous n'avons mis en évidence aucun effet du traitement sur le poids des poussins à la naissance, la longueur des os, le poids du foie, du cour et des poumons, ni sur les teneurs des muscles en ADN, ARN et en protéines. Nous en concluons que l'administration in ovo de IGF-l exogène à $j 7$ et j14 ne stimule pas la croissance embryonnaire du poulet.

IGF-I / poulet / embryon / croissance 


\section{INTRODUCTION}

There is considerable evidence of an association between somatomedins (insulinlike growth factors) and growth. It has been shown that administration of somatomedins can restore growth in growthretarded animals: Snell dwarf mice (Van Buul-Offers and Van den Brande, 1979) and hypophysectomized rats (Schoenle et al, 1982). However, there is little in the way of direct evidence that somatomedins stimulate growth of normal animals in vivo. Recently, it has been reported that exogenous IGF-I can also stimulate growth in normal rats (Hizuka et al, 1986), though other experiments have been unable to confirm this result. No such experiments have been reported in the fetus although it has been reported that IGF-I administration on $\mathrm{d} 2$ stimulates organogenesis in the early chick embryo (Girbau et al, 1987).

Although there have been no in vivo studies on the effects of IGF-I in the fetus, it is clear that somatomedins can stimulate metabolic processes and mitosis in a number of embryonic tissues in vivo (Rechler et al, 1976; Cynober et al, 1985). It is also known that many fetal tissues can synthesize somatomedins (d'Ercole et al, 1976, 1980). Despite these findings, the association between somatomedins and growth in the fetus is less compelling that in the postnatal animal. Although growth hormone levels and growth rates are high in the fetus, somatomedin levels, with the exception of IGF-II in some species, are generally low (d'Ercole et al, 1976; Brinsmead and Liggins, 1979; Charrier, 1980). Somatomedin levels in the fetus can be increased by, for example, insulin administration (Hill and Milner, 1980; Spencer et al, 1983), but such changes are not associated with increased growth in utero (Garssen et al, 1983; Cooke and Nicoll, 1984).
We have, therefore, attempted to directly investigate the effects of IGF-I on fetal growth in vivo using the chick embryo as a model.

\section{MATERIALS AND METHODS}

Eggs were collected on the day of laying and placed in a standard egg incubator. After $7 \mathrm{~d}$ the eggs were checked for viability and unfertilized eggs were discarded. Twenty-five eggs were selected at random and injected through the shell into the allantoic sac with $50 \mu \mathrm{l}$ saline and the eggs resealed with paraffin wax. A further 25 eggs were injected with a similar volume of saline containing $500 \mathrm{ng}$ IGF-I purified from human plasma (Spencer EM et al, 1983); the IGF showed identical amino-acid composition and sequence to that purified by Rinderknecht and Humbel (1978). All eggs were replaced and the incubation continued. The embryos were given a similar second injection of either saline or IGF$\mathrm{I}$ as appropriate at $\mathrm{d} 14$ and incubation continued through to hatching on $\mathrm{d} 21$ when the chicks were killed.

The chicks were anesthetized with $\mathrm{CO}_{2}$, bled by cardiac puncture, killed by cervical dislocation and their sex determined. The blood was rapidly centrifuged and the plasma frozen at $-20{ }^{\circ} \mathrm{C}$ for later determination of plasma IGF-1 levels (Spencer et al, 1987).

The chick carcasses were weighed and dissected and the weights of heart, liver, lungs and yolk sac were recorded. As an indication of bone growth, the length of the lower leg was measured (from the proximal end of the tarsometatarsus to the distal end of the third phalanx of the third digit) and the tibiotarsus was dissected out as a marker bone for length, breadth and weight measurements.

Thigh muscle was removed, weighed and frozen in liquid nitrogen and stored at $-20^{\circ} \mathrm{C}$ for later measurement of DNA, RNA and protein content (Wannemacher et al, 1965; Munro and Fleck, 1966; Abraham et al, 1972).

The sternae were removed, cleaned of muscle, divided and placed in Ham's F-10 medium containing antibiotics and $1 \mu \mathrm{Ci} / \mathrm{ml}$ [ [35 $\mathrm{S}$ $\mathrm{Na}_{2} \mathrm{SO}_{4}$ at $37^{\circ} \mathrm{C}$. The cartilage with ${ }^{35} \mathrm{SO}_{4}$ was incubated for $6 \mathrm{~h}$. The cartilage was then 
washed well to remove unincorporated label, weighed, digested in 3 mol..$^{-1} \mathrm{NaOH}$ and the uptake of label counted.

\section{RESULTS}

No differences were found between the egg weights for the IGF-I treated and control groups on both $d 7$ and 14 , and there were no significant differences $(P>0.05)$ between IGF-I treated and control chicks with regard to body weight, leg length, tibiotarsus size or organ weight (table I). There was, therefore, no effect on any gross estimates of body growth. As there were no difference between the sexes, these data were pooled.

There were indications that there had been an effect in increasing metabolism and cell growth. There was an increase $(P<0.02)$ in basal $35 \mathrm{SO}_{4}$ uptake in the cartilage $(2696 \pm 11 \mathrm{dpm} / \mathrm{mg}$ and $2173 \pm 171$

Table I. The effect of administration of $500 \mathrm{ng}$ IGF-I to chick embryo, at 7 and $14 \mathrm{~d}$ of age, on body weight, shank-toe length and various organ weights at hatching. Values are means \pm SE.

$$
\begin{array}{ll}
I G F-I & \text { Control } \\
(n=24) & (n=25)
\end{array}
$$

$\begin{array}{lrr}\text { Weight }(\mathrm{g}) & 45.66 \pm 0.53 & 46.55 \pm 0.66 \\ \text { Yolk sac }(\mathrm{g}) & 6.25 \pm 0.33 & 5.87 \pm 0.27 \\ \text { Wt }- \text { Yolk }(\mathrm{g}) & 39.76 \pm 0.52 & 40.69 \pm 0.51 \\ \text { Length }(\mathrm{cm})^{\star} & 4.89 \pm 0.04 & 4.88 \pm 0.03 \\ \text { Lung (g) } & 0.47 \pm 0.02 & 0.46 \pm 0.02 \\ \text { Liver (g) } & 1.09 \pm 0.04 & 1.07 \pm 0.03 \\ \text { Heart (g) } & 0.28 \pm 0.02 & 0.31 \pm 0.01 \\ \text { Bone length }(\mathrm{cm})^{\star \star} & 3.17 \pm 0.02 & 3.17 \pm 0.01\end{array}$

* Proximal end of tarsometatarsus to the distal end of the third phalanx of the third digit. * Tibiotarsus $\mathrm{dpm} / \mathrm{mg}$ cartilage for treated and control chicks, respectively) tending to confirm the fact that excess IGF-I had been present in the treated chicks. Serial dilutions of chick plasma failed to give a dose-response curve in the IGF radioimmunoassay and it was not possible to determine whether there were increased levels of IGF-I in the plasma of the treated chicks by this method.

There was no statistically significant effect of treatment on DNA, RNA or protein content of muscle (fig 1). Although there was a numerically slightly higher level of these parameters and a slightly greater muscle mass in the treated group, the indices for hypertrophic growth (protein/DNA) and biosynthetic activity (RNADNA) were lower in the IGF-I treated group; (protein/ DNA:73.31 \pm 3.13 and $83.27 \pm 5.00, P>$ 0.05 ; RNA/DNA $2.25 \pm 0.05$ and $2.66 \pm$ $0.20 ; P<0.05$ for treated and control chicks, respectively).

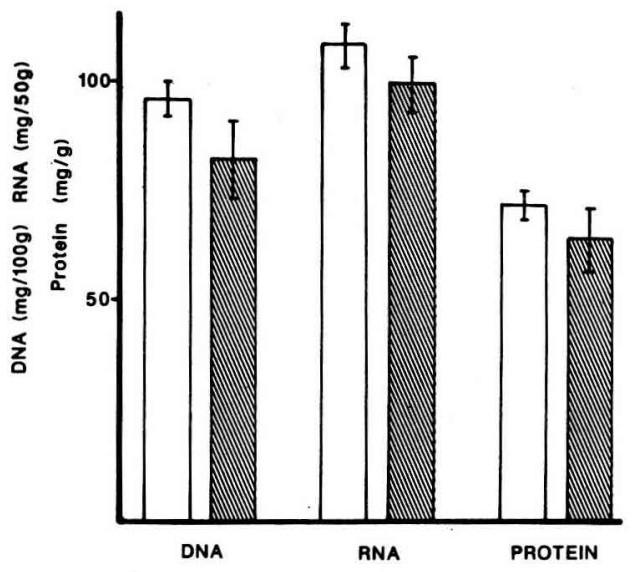

Fig 1. Content of DNA (mg/100 g muscle), RNA ( $\mathrm{mg} / 50 \mathrm{~g}$ muscle) and protein ( $\mathrm{mg} / \mathrm{g}$ muscle) in the thigh muscle from chick embryos treated with $2 \times 500 \mathrm{ng}$ IGF-I (open bars) or saline (shaded bars). Data are the mean \pm SE. 


\section{DISCUSSION}

The lack of effect of IGF-I administration on the weight gain of the chick embryo suggests either that this hormone does not have an important role in the growth of the chick embryo or that endogenous IGF-I production stimulates growth maximally. In spite of the stimulatory activity of IGF-I on embryonic and fetal tissues in vitro (Rechler et al, 1976; Ashton and Francis, 1978; Weidman and Bala, 1980) and the ability of tissues such as chick liver cells (Haselbacher et al, 1980) and chick cartilage (Burch et al, 1986), to synthesize IGF-I (d'Ercole et al, 1976), it is widely believed that IGF-II may be the somatomedin involved in growth promotion in the fetus (Moses et al, 1980). IGF-I blood levels are low in fetal life compared to postnatal values (Gluckman et al, 1983; Spencer GSG et al, 1983); in contrast, IGF-ll levels were found to be high in the fetus of some species (Moses et al, 1980). However, a direct study of the effect of IGF-II on fetal growth has failed to show any positive effect on the growth of pig fetuses (Spencer, 1986).

Although the principal receptor for IGFII (the so-called type II receptor) is absent in chick embryo tissues (Bassas et al, 1988) and IGF-II crossreacts more weakly with the type-1 receptor than IGF-I (Rechler et al, 1983), it has been suggested that IGF-II may act through the type 1 receptor in the chicken (Kasuga et al, 1982; Clairmont and Czech, 1989). Thus it may be interesting to examine the effects of similar administration of IGF-II on chick embryo growth.

The biochemical measurements in the present study indicated that IGF-I in the chick embryo increased sulphate uptake into cartilage. This demonstrates that the administered hormone was active at the tissue level and had an effect on cell metabolism. This would concur with the stimulation of organogenesis by IGF-I in the chick embryos studied at an earlier stage by Girbau et al (1987), but in our study IGF-I did not stimulate growth. The numerically higher DNA content of the thigh muscle, coupled with a slightly higher muscle mass, suggests that IGF-I increased cellularity in the treated group. However, the indices for hypertrophic growth (protein/DNA) and biosynthetic activity (RNA/DNA) were lower in this group.

There are a number of possible reasons for the lack of a growth stimulating effect of the IGF-I in this study:

- the use of human IGF in the chick embryo may be a factor. Although chick cells synthesize a somatomedin similar to IGF-I (Haselbacher et al, 1980; Burch et al, 1986), on starting the study we were concerned about the possible heterogeneity between human and avian IGF-I. Recently, however, it has been reported that chicken and human IGF-I show almost complete homogeneity in the first 30 residues at the $\mathrm{N}$-terminus (Dawe et al, 1988);

- the dose may have been inappropriate, but there was no evident effect of a 10 -fold greater dose ( $5 \mu \mathrm{g}$ per injection) given to 3 other embryos (data not shown);

- the method and timing of administration may not have been suitable, but a similar administration of IGF-I at an earlier stage of development has been shown to affect the chick embryos (Girbau et al, 1987);

- the lack of binding protein in the injection medium may have allowed clearance of the hormone to be too rapid for it to have an appreciable effect, or the binding protein may have specific actions. Not much is known regarding avian IGF binding proteins. Recently Armstrong et al (1988) have indicated that they are of similar size to those found in the human, but of the binding proteins in the chick embryo nothing is known. In post-natal mammalian plasma it is thought that native IGF is rap- 
idly "inactivated" by the large, inhibitory, $\mathrm{GH}$ dependent binding protein. If a chick embryo IGF-binding protein exists, it may be similar to the recently purified amniotic fluid binding protein (the non $\mathrm{GH}$ dependent $33 \mathrm{kDa}$ binding protein) which is present in the fetus (Drop et al, 1979, 1984). In contrast to the larger, $\mathrm{GH}$ dependent binding protein, the $33 \mathrm{kDa}$ protein found in early and mid-gestation human fetuses has been shown to potentiate, rather than inhibit, the action of IGF-I (EIgin et al, 1984);

- in the absence (or large reduction) of $150 \mathrm{kDa}$ binding proteins, the half-life of IGF-I in the hypophysectomized rat is less than 30 min (Zapf et al, 1986) and the effects of IGF-I on growth in hypophysectomized rats has only been observed with continuous infusion or daily injections (Schoenle et al, 1982). Thus weekly injections may have been inadequate to produce a response even in the "closed" system of the egg;

- the other major reason for the lack of effect could be that endogenous IGF-I does not stimulate growth of the chick embryo through endocrine secretion of IGFs, but rather via local action as autocrine/ paracrine factors. Local production could be having a maximal effect; direct proof of this may be tested by injecting blocking IGF antiserum. Additionally, these chick embryos are normal embryos with normal IGF-I synthesis. Only one of a large number of studies has been able to show that exogenous IGF-I could stimulate growth in a normal animal (Hizuka et al, 1986) Thus endogenous IGF-I production in the normal chick embryo may be sufficient to allow maximal growth.

From these results we conclude that administration of exogenous IGF-I to the chick embryo at 7 and $14 \mathrm{~d}$ is not able to stimulate further weight gain in the chick embryo.

\section{ACKNOWLEDGMENTS}

The authors gratefully acknowledge the help of AMAW Welling and $\mathrm{HJ}$ van Boxtel in these studies.

\section{REFERENCES}

Abraham GH, Scaletta C, Vaughan JA (1972) Modified diphenylamine reaction for increased sensitivity. Anal Biochem 49, 547549

Armstrong DG, McKay CA, Goddard C (1988) Insulin-like growth factor binding proteins in chicken serum. J Endocrinol 117 (suppl), abstr 241

Ashton IK, Francis MJO (1978) Response of chondrocytes isolated from human fetal cartilage to plasma somatomedin activity. $J$ Endocrinol 76, 473-477

Bassas L, Lesniak MA, Serrano J, Roth J, de Pablo F (1988) Developmental regulation of insulin and type-I insulin-like growth factor receptor and absence of type-II receptors in chicken-embryo tissues. Diabetes 37, 637644

Brinsmead MW, Liggins GC (1979) Serum somatomedin activity after hypophysectomy and during parturition in fetal lambs. Endocrinology 105, 297-305

Burch WM, Weir S, van Wyk JJ (1986) Embryonic chick cartilage produces its own somatomedin-like peptide to stimulate cartilage growth in vitro. Endocrinology 119, 13701376

Charrier KB (1980) Somatomedin-A (SM-A) bioactivity in serum and amniotic fluid as related to weight in the fetal pig. Reprod Nutr Dev 20, 301-310

Clairmont J, Czech MP (1989) Chicken and Xenopus mannose-6-phosphate receptors fail to bind insulin-like growth factor II. J Biol Chem 264, 16390-16393

Cooke PS, Nicoll CS (1984) Role of insulin in the growth of fetal rat tissues. Endocrinology $114,638-643$

Cynober L, Aussel C, Chatelain P, Vaubourdolle M, Agneray J, Ekindjian G (1985) Insulin-like 
growth factor-1/somatomedin-C action on 2deoxyglucose and- amino isobutyrate uptake in chick embryo fibroblasts. Biochimie 67, 1185-1190

Dawe SR, Francis GL, McNamara PJ, Wallace JC, Ballard FJ (1988) Purification, partial sequences and properties of chicken insulinlike growth factors. $J$ Endocrinol 117, 173181

Drop SL, Valiquette G, Guyda HJ, Corvol MT, Posner BI (1979) Partial purification and characterization of a binding protein for insulin-like activity (ILAs) in human amniotic fluid: a possible inhibitor of insulin-like activity. Acta Endocrinol 90, 505-518

Drop SL, Kortleve DJ, Guyda HJ, Posner BI (1984) Immunoassay of a somatomedin binding protein from human amniotic fluid: levels in fetal, neonatal and adult sera. J Clin Endocrinol Metab 59, 908-915

Elgin RG, Busby WH, Clemmons DR (1987) An insulin-like growth factor (IGF) binding protein enhances the biologic response to IGF-I. Proc Natl Acad Sci USA 84, 3254-3258

d'Ercole AJ, Foushee DB, Underwood LE (1976) Somatomedin-C receptor ontogeny and levels in porcine fetal and human cord serum. J Clin Endocrinol Metab 43, 10691070

d'Ercole AJ, Applewhite GT, Underwood LE (1980) Evidence that somatomedin is synthesized by multiple tissues in the fetus. Dev Biol 75, 315-328

Garssen GJ, Spencer GSG, Colenbrander B, Macdonald AA, Hill DJ (1983) Lack of effect of chronic hyperinsulinemia on growth and body composition in the fetal pig. Biol Neonate 44, 234-242

Girbau M, Gomez JA, Lesniak MA, de Pablo F (1987) Insulin and insulin-like growth factor I both stimulate metabolism, growth and differentiation in the postneurula chick embryo. Endocrinology 121, 1477-1482

Gluckman PD, Johnson-Barrett JJ, Butler JH, Edgar BW, Gunn TR (1983) Studies of insulin-like growth factor-I and II by specific radioligand assays in umbilical cord blood. Clin Endocrinol 19, 405-413

Haselbacher GK, Andres RY, Humbel RE (1980) Evidence for the synthesis of a somatomedin similar to insulin-like growth factor I by chick embryo liver cells. Eur $J$ Biochem 111, 245-250

Hill DJ, Milner RDG (1980) Increased somatomedin and cartilage metabolic activity in rabbit fetuses injected with insulin in utero. Diabetologia 19, 143-147

Hizuka N, Takano K, Shizume K, Asakawa K, Miyakawa M, Tanaka I, Horikawa R (1986) Insulin-like growth factor-I stimulates growth in normal growing rats. Eur J Pharmacol 125, 143-146

Kasuga $M$, Van Obberghan E, Nissley SP, Rechler MM (1982) Structure of the insulinlike growth factor receptor in chicken embryo fibroblasts. Proc Natl Acad Sci USA 79, 1864-1868

Moses AC, Nissley SP, Short PA, Rechler HH, White RM, Knight AB, Higa OZ (1980) Increased levels of multiplication stimulating activity, an insulin-like growth factor, in fetal rat serum. Proc Natl Acad Sci USA 77, 36493653

Munro HN, Fleck A (1966) The determination of nucleic acids. Methods Biochem Anal 14, 113-176

Rechler MM, Kasuga M, Sasaki N, de Vroede MA, Romanus JA, Nissley SP (1983) Properties of insulin-like growth factor receptor subtypes. In: Insulin-Like Growth Factors / Somatomedins (Spencer EM, ed) de Gruyter, Berlin, 459-490

Rechler MM, Podskalny JM, Nissley SP (1976) Interaction of multiplication-stimulating activity with chick embryo fibroblasts demonstrates a growth receptor. Nature 259, 134136

Rinderknecht E, Humbel RE (1978) The amino acid sequence of human insulin-like growth factor $I$ and its structural homology with proinsulin. J Biol Chem 253, 2769-2776

Schoenle E, Zapf J, Humbel RE, Froesch ER (1982) Insulin-like growth factor-I stimulates growth in hypophysectomized rats. Nature 296, 252-253

Spencer EM, Ross M, Smith B (1983) The identity of insulin-like growth factors I and II with somatomedins $\mathrm{C}$ and $\mathrm{A}$ and homology with rat IGF-I and II. In: Insulin-Like Growth Factors / Somatomedins (Spencer EM, ed) de Gruyter, Berlin, 81-96 
Spencer GSG (1986) Hormonal Influences on Growth of the Fetal Pig. In: Swine in Biomedical Research (Tumbleson ME, ed) Plenum Publishing Corp, NY, Vol 2, 1205-1213

Spencer GSG, Hill DJ, Garssen GJ, Macdonald AA, Colenbrander B (1983) Somatomedin activity and growth hormone levels in the fetal pig: effect of chronic hyperinsulinaemia. JEndocrinol 96, 107-114

Spencer GSG, Hallett KG, Fadlalla AM, Spencer EM (1987) Temporal changes in the circulating levels of growth hormone, insulin, somatomedin- $\mathrm{C}$ and thyroxine in sheep during active immunization against somatostatin. Endocrinol Exp 21, 299-306

Van Buul-Offers, Van den Brande JL (1979) Effect of growth hormone and peptide fractions containing somatomedin activity on growth and cartilage metabolism of Snell dwarf mice. Acta Endocrinol 92, 242-257

Wannemacher RW, Banks WL, Wunner WH (1965) Use of a single tissue extract to determine cellular protein and nucleic acid concentrations and rate of amino acid incorporation. Anal Biochem 11, 320-326

Weidman ER, Bala RM (1980) Direct mitogenic effects of human somatomedin on human embryonic lung fibroblasts. Biochem Biophys Res Commun 92, 577-585

Zapf J, Hauri C, Waldvogel $M$, Froesch ER (1986) Acute metabolic effects and half-lives of intravenously administered insulin-like growth factors $\mathrm{I}$ and $\mathrm{II}$ in normal and hypophysectomized rats. $J$ Clin Invest $77,1768-$ 1775 